\title{
Diversity, Abundance, and Distribution Patterns of Natural Enemy Insects on Chili (Capsicum annum L.) in Bincau Village, Banjar Regency, South Kalimantan
}

\author{
Manap Trianto, Fajri Marisa, and Moh Dahri Kisman \\ Faculty of Biology, Universitas Gadjah Mada, Sleman, Special Region of Yogyakarta, Indonesia
}

Corresponding author: manaptrianto@mail.ugm.ac.id

\begin{abstract}
The chili cultivation practice will influence the soil structure and the variety of insects that are produced. The management of pests using pesticides has been one of the traditional cultivation practices carried out by farmers. This study aims to determine the diversity, abundance, and distribution patterns of natural enemy insects in chili plantation (Capsicum annum L.) at Bincau Village, Martapura District, Banjar Regency, South Kalimantan. The sample was collected by pitfall trap, yellow pan trap, and sweep net method. Obtained data were analyzed by Shannon Wienner index ( $\left.\mathrm{H}^{\prime}\right)$, Meyer abundance index, Morisita index (Id), and PCA method for environmental parameter analysis. The results showed the diversity of natural enemy insects on chili plants was moderate $\left(\mathrm{H}^{\prime}=2.396\right)$. Furthermore, the highest abundance in research is demonstrated on Hymenoptera order, which consisted of 9 families, 16 species, and 1,009 individuals. The distribution pattern of natural enemy insects in chili plantations is clustered (Id > 1). Based on the PCA analysis method, the temperature has the most impact on natural enemy insects' presence in this study.
\end{abstract}

Keywords: Diversity, Abundance, Distribution Patterns, Insect, Chili

\section{Introduction}

Chili (Capsicum annum L.) pepper is mostly found worldwide as a seasoning (Sativa et al., 2017). It has a phytochemical composition, and a lot of its nutritional properties Chili occupies the largest crop area, around 2.5 million ha, among the vegetables cultivated in Asia. In Indonesia, the annual production of Chili reaches approximately 5 percent of the global supply (Mariyono \& Bhattarai, 2009). Chili has become a potential commodity of vegetables with high economic value and potentially continuity developed (Tsurayya \& Kartika, 2015; Adnyana et al., 2020). Since 2001, Chili production has increased by an average of 20 percent per year, from about 190,000 hectares to cross more than 1 million tons in 2005, accounting for about 12 percent of vegetables' production. In Java, with Western Java, more than 60 percent of Chilli is produced (198,000 tons)(Morgan \& Shearer, 2007).

Chili (Capsicum annum L.) is a very complex plant even though it grows rapidly. Several factors are affecting Chili's productivity, such as soil, irrigation, fertilizing. (Trianto et al., 2020). In Indonesia, the seasonal and frequent fluctuations in chili prices are relatively high, more than for other vegetables and rice, and pose a significant risk to chili farmers. Crop production, annual supply, and market stability are also significantly affected by losses caused by insect infestation (Adnyana et al., 2020). Indonesian farmer has been applying insecticides to control the disease for more than decades. Pesticides 
increase crop yields, minimize production costs, and enhance quality, thus increasing farmers' income. However, it has been found that the use of chemical insecticides is hazardous to human and animal health or the environment $\mathrm{Hu}, 2020$; PazikowskaSapota et al., 2020).

Pesticides promise the successful control of harmful bugs, but the risks associated with their use have exceeded their beneficial effects. Nonselective pesticides and the targeted ones eliminate animals that act as a natural enemy, such as predatory insects and parasitoids (Putra \& Utami, 2020). Application of chemical insecticides has still occurred in Bincau Village, Banjar Regency, South Kalimantan, which possible to influence the ecology of natural enemy insects in chili plantations. Therefore, this study was purposed to calculate the diversity, abundance, and distribution pattern of natural enemy insects on chili (Capsicum annum L.) plantations in Bincau Village, Banjar Regency, South Kalimantan. This study aimed to determine the presence of natural enemies in chili cultivation, which can be used as initial information in reducing natural pest populations in an ecosystem.

\section{Material and Method}

This research was conducted at Chili Plantation, Bincau Village, Banjar Regency, South Kalimantan Province (Figure 1). Data were collected from April to May 2020. Sample was identified in the Entomology Laboratory, Faculty of Biology, Universitas Gadjah Mada.

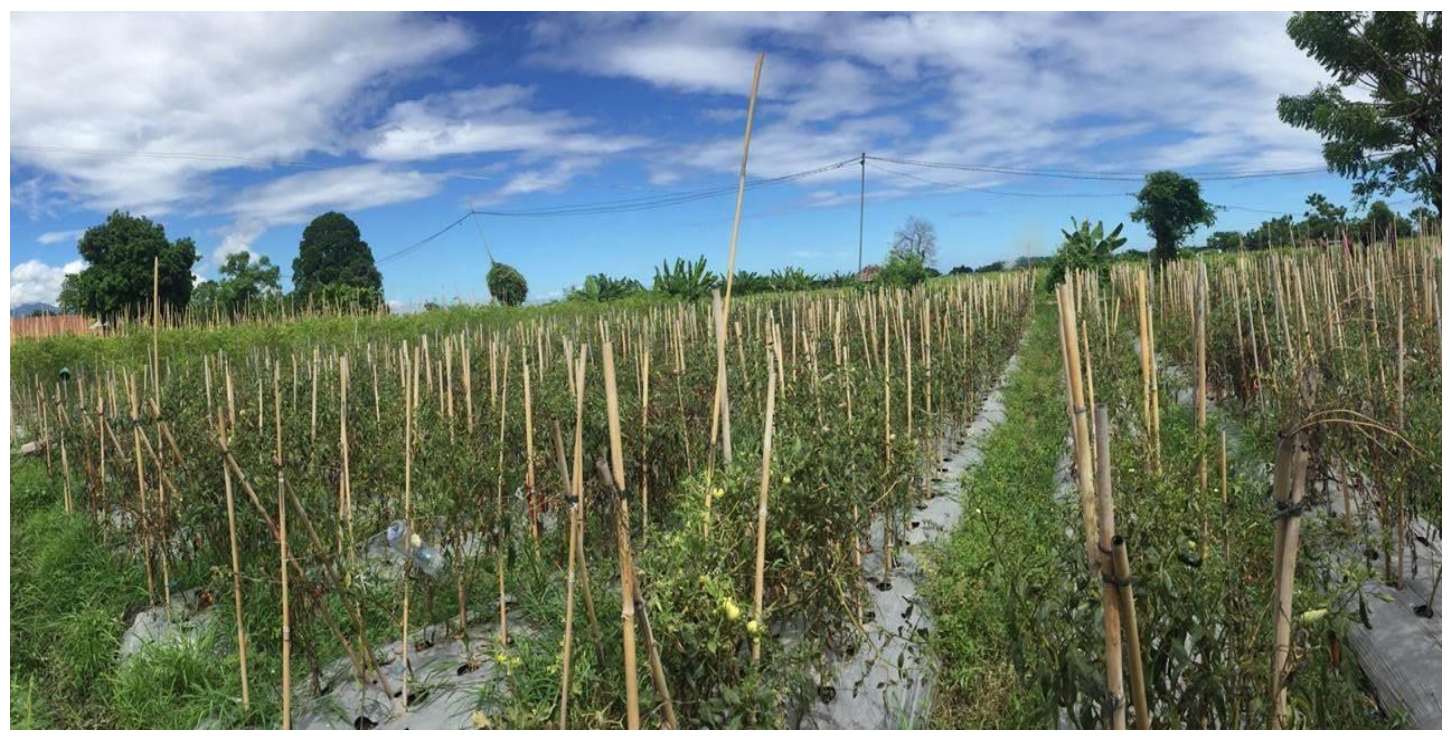

Figure 1. The sampling area in chili plantation

Sampling was carried out using a $2 \times 2 \mathrm{~m}$ plot of 25 plots and was carried out randomly in the sampling area (chili plantations). Samples were taken four times to obtain maximum results. Insects in each plot were caught by the direct method using a sweep net, yellow pan trap, and pitfall trap. The traps are set twice a day, in the morning $(07.00 \mathrm{am})$ and in the afternoon (4.00 pm). The sweep net exertion by swinging it along the chili plantation bed while walking. The swing is done vertically (up and down). Each 
plot is placed in 1 trap in the form of a yellow pan trap and a pitfall trap. The yellow pan trap used a yellow container with a diameter of $15 \mathrm{~cm}$, while the pitfall trap used a plastic cup with $5 \mathrm{~cm}$ of diameters and $15 \mathrm{~cm}$ of high. Both traps were filled with a detergent solution in a ratio of 1:2 (water and detergent). Yellow pan traps are placed in the open area to be attracted to the yellow color, while pitfall traps are installed by burying them with the glass mouth parallel to the ground. The insects obtained were then washed with distilled water and transferred to a sample bottle containing $70 \%$ alcohol for identification.

Identification of insect species and their roles was made using Hymenoptera of The World, Annotated Keys to the Genera of Neartic Chalcidoidea, A Handbook of The Families of Neartic Chalcidoidea (Hymenoptera), and Manual of the New World Genera of the Family Braconidae (Hymenoptera). Besides, the identification process is also carried out using identification journals such as (Gunawardene \& Taylor, 2012). The abiotic conditions measured in this study were temperature using a thermometer, humidity using a hygrometer, and light intensity using a lux meter. Furthermore, the results obtained will be analyzed using the PCA method using PAST3 software (Trianto \& Purwanto, 2020; Yudha et al., 2019).

\title{
Data Analysis
}

All data were analyzed using Biodiversity Pro software. Several indexes used in this research were the diversity index of Shannon-Wienner, Shannon-Evennes and dominance index of Simpson, the abundance of Meyer, and the distribution pattern analyzed by the index of Morisita (Magurran, 2004; Schinner et al., 2014). Other analyses used were diversity indices using the following:

\section{Diversity Index $(\mathrm{H}=-\Sigma(\mathrm{ni} / \mathrm{N}) \ln (\mathrm{ni} / \mathrm{N}))$}

Information:

H: Diversity index

ni: Number of individual types

$\mathrm{N}$ : Total number of individuals

\author{
Abundance Index ( $=$ IS / A) \\ Information: \\ $\mathrm{N}$ : Abundance index \\ IS: Median number of individual \\ A: Area of the sampling point
}

\author{
Distribution Pattern $(I d=n((\Sigma x i 2-\Sigma x i) /(\Sigma x i) 2-\Sigma x i)))$ \\ Information: \\ Id: Morisita index \\ $\mathrm{n}$ : Total of plot \\ xi: Number of individual of i-th species
}


While the standardized of Morisita index calculated by the equation:

$$
\begin{array}{ll}
\text { Ip : } 0.5+0.5((\text { Id }-M c) /(n-M c)) & ; \text { if Id } \geq \text { Mc }>1 \\
\text { Ip : } 0.5((\text { Id }-1)-(M c-1)) & \text {; if } M c>\text { Id } \geq 1 \\
\text { Ip : } 0.5((I d-1) /(M u-1)) & \text {; if } 1>\text { Id }>\text { Mu } \\
\text { Ip : } 0.5+0.5((\text { Id }- \text { Mu }) /(M u)) & \text {; if } 1>M u>\text { Id }
\end{array}
$$

Furthermore, a distribution pattern is calculated by the equation of $\mathrm{Mu}$ and $\mathrm{Mc}$ :

Information:

$$
\begin{aligned}
& M u=\left(x^{2} 0.975-n+\Sigma x i\right) /(\Sigma x i)-1 \\
& M c=\left(x^{2} 0.025-n+\Sigma x i\right) /(\Sigma x i)-1
\end{aligned}
$$

$\mathrm{Mu}$ : Morisita index on the distribution pattern of uniform

Mc: Morisita index on the distribution pattern of cluster

$\mathrm{x}^{2} 0.975$ : The value of $\mathrm{x}^{2}$ with $\mathrm{n}-1$ degree of freedom and confidence interval $97.5 \%$

$\mathrm{x}^{2} 0.025$ : The value of $\mathrm{x}^{2}$ with $\mathrm{n}-1$ degree of freedom and confidence interval $2.5 \%$

n: Number of plot

$\mathrm{xi}$ : Number of individual on i-th plot

Criteria of distribution pattern:

Jika Ip < 0: Uniform

Jika Ip = 0: Random

Jika Ip > 0: Cluster

\section{Principal Component Analysis (PCA)}

Data on abiotic environmental conditions with the number of individual natural enemy insects in chili plantations were analyzed by the PCA method with PAST3 software (Trianto \& Purwanto, 2020; Yudha et al., 2019).

\section{Results and Discussion}

\begin{tabular}{|c|c|c|c|c|}
\hline No & Sampling Time & $\mathbf{H}^{\prime}$ & Value* & Category* \\
\hline 1 & First & 2,322 & $H^{\prime} \geq 2.0$ & Moderate \\
\hline 2 & Second & 2,361 & $H^{\prime} \geq 2.0$ & Moderate \\
\hline 3 & Third & 2,336 & $H^{\prime} \geq 2.0$ & Moderate \\
\hline 4 & Fourth & 2,885 & $H^{\prime} \geq 2.0$ & Moderate \\
\hline 5 & Fifth & 2,086 & $H^{\prime} \geq 2.0$ & Moderate \\
\hline 6 & Sixth & 2,220 & $H^{\prime} \geq 2.0$ & Moderate \\
\hline 7 & Seventh & 2,163 & $H^{\prime} \geq 2.0$ & Moderate \\
\hline 8 & Eighth & 2,690 & $H^{\prime} \geq 2.0$ & Moderate \\
\hline 9 & Ninth & 2,461 & $H^{\prime} \geq 2.0$ & Moderate \\
\hline 10 & Tenth & 2,432 & $H^{\prime} \geq 2.0$ & Moderate \\
\hline \multicolumn{2}{|r|}{ Mean } & 2,396 & $H^{\prime} \geq 2.0$ & Moderate \\
\hline
\end{tabular}

\subsection{Results}

\section{Diversity of Natural Enemy Insect}

This study indicates that insects' natural enemy's diversity index in chili plants is moderate (2.396) (Table 1).

Table 1. Shannon-Wienner $\left(\mathrm{H}^{\prime}\right)$ diversity index of natural enemy insects in chili plants 


\section{The abundance of Natural Enemy Insect}

There are seven insect orders (1.196 individuals and 17 species), which acted as predators, and three insect orders (236 individuals and 13 species) as parasitoid insects in the chili plantations at the research location. The order with the highest number of individuals and species is Hymenoptera (Table 2).

Table 2. The role and number of individuals of natural enemy insect species in chili plantation by sweep net, yellow pan trap, and pitfall trap

\begin{tabular}{|c|c|c|c|c|c|}
\hline \multirow{2}{*}{$\begin{array}{l}\text { Role of } \\
\text { Insect }\end{array}$} & \multirow{2}{*}{ Species } & \multicolumn{3}{|c|}{ Methods } & \multirow{2}{*}{ Total } \\
\hline & & $\begin{array}{c}\text { Sweep } \\
\text { net }\end{array}$ & $\begin{array}{c}\text { Yellow pan } \\
\text { trap }\end{array}$ & $\begin{array}{c}\text { Pitfall } \\
\text { trap }\end{array}$ & \\
\hline \multirow[t]{17}{*}{ Predator } & Agriocnemis pygmaea & 57 & 27 & 43 & 127 \\
\hline & Orthetrum sabina & 6 & 2 & 4 & 12 \\
\hline & Pantala flavescens & 3 & 0 & 0 & 3 \\
\hline & Ischiodon scutellaris & 7 & 0 & 2 & 9 \\
\hline & Cyrtorhinus lividipennis & 6 & 1 & 5 & 12 \\
\hline & Anoplolepis gracilipes & 139 & 32 & 86 & 257 \\
\hline & Dolichoderus thoracicus & 21 & 4 & 10 & 35 \\
\hline & Odontoponera denticulata & 4 & 1 & 1 & 6 \\
\hline & Paratrechina longicornis & 372 & 68 & 144 & 584 \\
\hline & Vespa analis & 2 & 0 & 0 & 2 \\
\hline & Conocephalus longipennis & 17 & 7 & 8 & 32 \\
\hline & Metioche vittaticollis & 11 & 5 & 9 & 25 \\
\hline & Chilocorus nigritus & 18 & 9 & 7 & 34 \\
\hline & Coccinela repanda & 2 & 1 & 0 & 3 \\
\hline & C. transversalis & 28 & 11 & 6 & 45 \\
\hline & Coleosoma octomaculatum & 2 & 0 & 0 & 2 \\
\hline & Forficula auricularia & 5 & 1 & 2 & 8 \\
\hline \multirow[t]{14}{*}{ Parasitoid } & Anagrus optabilis & 2 & 1 & 1 & 4 \\
\hline & Apanteles glomeratus & 3 & 1 & 0 & 4 \\
\hline & Brachimeria femoralis & 4 & 3 & 4 & 11 \\
\hline & Cardiochiles nigriceps & 8 & 2 & 5 & 15 \\
\hline & C. saltator & 3 & 0 & 2 & 5 \\
\hline & Eurytoma dentata & 13 & 5 & 10 & 28 \\
\hline & Goryphus basilaris & 22 & 3 & 7 & 32 \\
\hline & Platygaster oryzae & 8 & 1 & 6 & 15 \\
\hline & Tamarixia radiata & 2 & 0 & 1 & 3 \\
\hline & Tetrastichus schoenobii & 2 & 1 & 2 & 5 \\
\hline & Trichopria drosophilae & 1 & 1 & 1 & 3 \\
\hline & Exorista sp. & 52 & 19 & 34 & 105 \\
\hline & Stylops sp. & 3 & 1 & 2 & 6 \\
\hline & Total & 823 & 207 & 402 & 1.432 \\
\hline
\end{tabular}

\section{Distribution Pattern of Natural Enemy Insect}

The ecosystem consisted of three basic distribution patterns, namely clustered, uniform, and random. In this study, the distribution pattern of natural enemy insects in chili plantations is clustered (Table 3). 
Table 3. Distribution pattern of natural enemy insect species in chili plantation

\begin{tabular}{clccccc}
\hline No & Sampling Time & Id & Mu & Mc & Ip & $\begin{array}{c}\text { Distribution } \\
\text { Pattern }\end{array}$ \\
\hline 1 & First & 1.68 & 0.98 & 1.04 & 0.56 & Clustered \\
2 & Second & 1.66 & 0.96 & 1.02 & 0.52 & Clustered \\
3 & Third & 1.68 & 0.98 & 1.04 & 0.56 & Clustered \\
4 & Fourth & 1.66 & 0.96 & 1.02 & 0.52 & Clustered \\
5 & Fifth & 1.67 & 0.97 & 1.03 & 0.54 & Clustered \\
6 & Sixth & 1.69 & 0.99 & 1.05 & 0.58 & Clustered \\
7 & Seventh & 1.68 & 0.98 & 1.04 & 0.56 & Clustered \\
8 & Eighth & 1.66 & 0.96 & 1.02 & 0.52 & Clustered \\
9 & Ninth & 1.66 & 0.96 & 1.02 & 0.52 & Clustered \\
10 & Tenth & 1.67 & 0.97 & 1.03 & 0.54 & Clustered \\
\hline
\end{tabular}

\section{Environmental Parameters}

The median temperature obtained is $27.72{ }^{\circ} \mathrm{C}$, humidity is $74.9 \%$, dan light intensity is 1117.8 (Tabel 4).

Table 4. Measurement of environmental parameters on chili plantation in Bincau Village, Banjar District, South Kalimantan

\begin{tabular}{clccc}
\hline No & Sampling Time & $\begin{array}{c}\text { Temperature } \\
\text { (C) }\end{array}$ & Humidity (\%) & $\begin{array}{c}\text { Light Intensity } \\
\text { (Lux) }\end{array}$ \\
\hline 1 & First & 27.2 & 73 & 1013 \\
2 & Second & 28.5 & 72 & 1052 \\
3 & Third & 27.3 & 76 & 1133 \\
4 & Fourth & 28.3 & 73 & 1081 \\
5 & Fifth & 27.0 & 75 & 1120 \\
6 & Sixth & 29.4 & 76 & 1143 \\
7 & Seventh & 28.5 & 78 & 1205 \\
8 & Eighth & 28.5 & 75 & 1109 \\
9 & Ninth & 27.0 & 74 & 1115 \\
10 & Tenth & 28.1 & 77 & 1207 \\
\hline \multicolumn{2}{r}{ Median } & 27.71 & 74.9 & 1117.8 \\
\hline
\end{tabular}

Correlation analysis between cluster yields eigenvalue and \% variance, as shown in Table 5. While the Scatter plot is shown in Figure 2, and the loading plot of the component is shown in Figure 3.

Table 5. Eigenvalue and \%Variance

\begin{tabular}{ccc}
\hline PC & Eigenvalue & \% variance \\
\hline 1 & 3541.12 & 85.296 \\
2 & 610.183 & 14.698 \\
3 & 0.265036 & 0.006384 \\
\hline
\end{tabular}




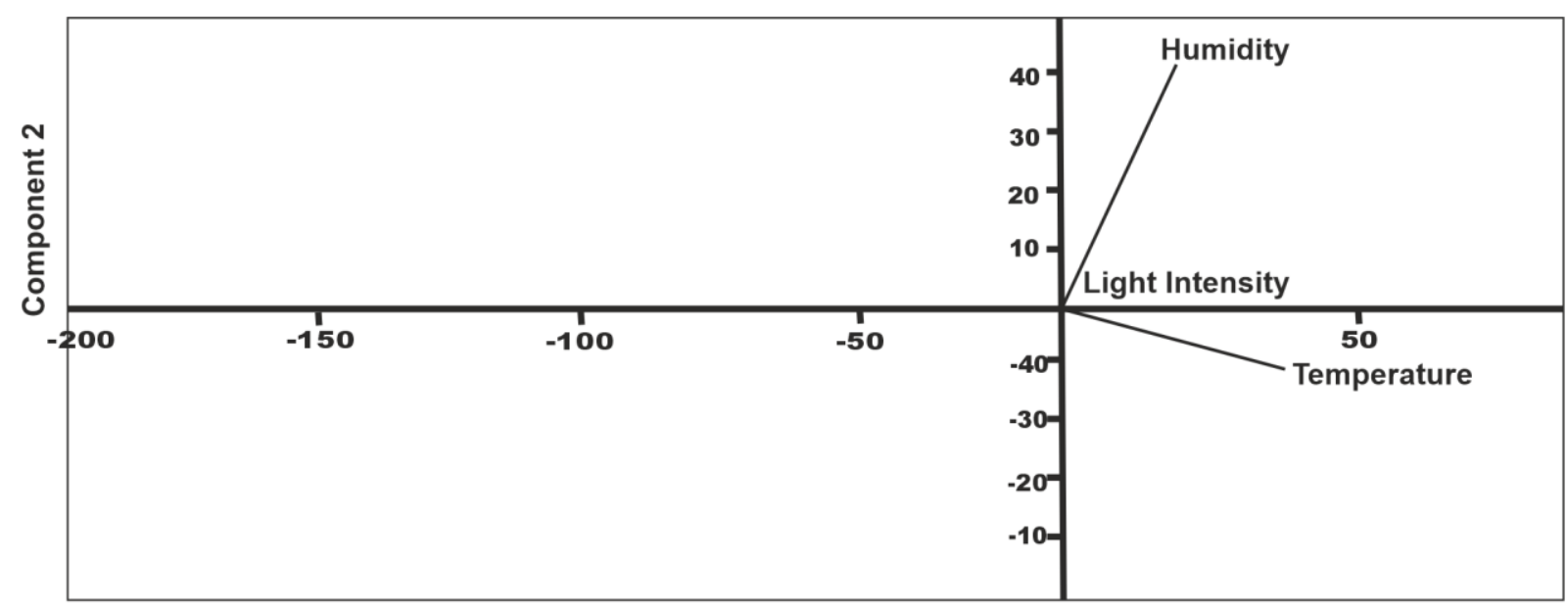

Component 1

Figure 2. The PCA results of the scatter plot

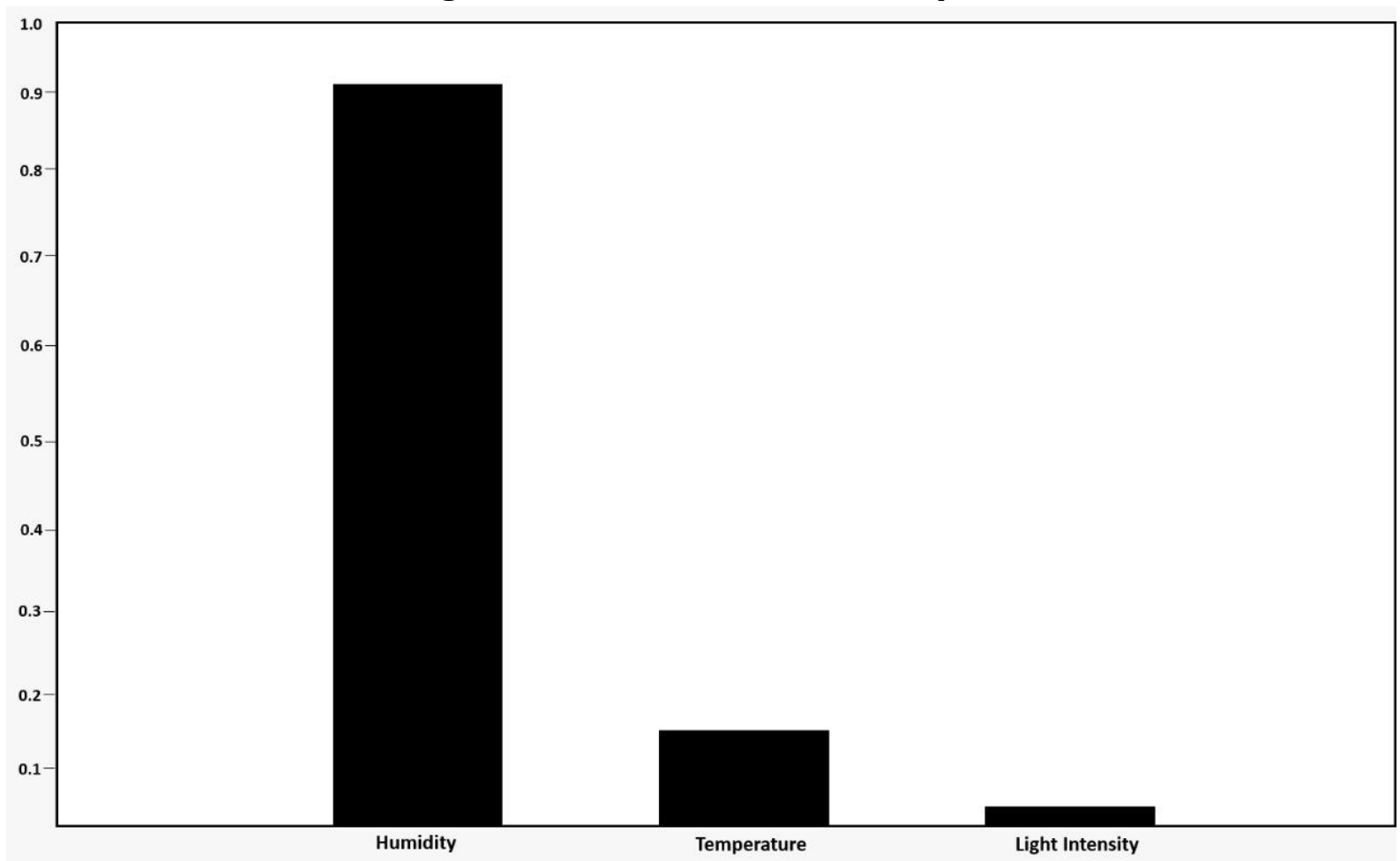

Figure 3. The loading plot of component

\subsection{Discussion}

\section{Diversity of Natural Enemy Insects}

Table 1 represented the diversity of natural enemy insects in chili plantations in Bincau Village was moderate. This is due to community activities' influence on natural enemy insects at the research location. The research location used is a location directly adjacent to the community house and other cultivated plants. On the left and right, it is directly adjacent to the residents' houses, while at the front, it is directly adjacent to the village road where there is a long bean planting area across it. It can also occur because 
there are not many types of plants found at the research location. The fewer plants found in an ecosystem will affect natural enemy insects' existence in the ecosystem (Kurniawati, 2015). It is consistent with research from Ghazali et al. (2016), who obtained results that the insects found on polyculture land were more abundant and varied than on monocultures. It was further explained that this could happen because plants' diversity influenced it in the area.

The natural enemy insect families that dominate in this study are Formicidae, Coccinellidae, and Braconidae. It follows the research results reported by Putra \& Utami (2020), who researched chili plants in Wiyoro Village, Banguntapan District, Bantul Regency, Yogyakarta Special Region. Souza et al. (2019) investigated red chili plantations in Pakem District, Sleman Regency, Yogyakarta Special Region, that the three families are natural enemy insect families that dominate in chili plantations. Furthermore, Souza et al. (2019) added that the diversity of natural enemy insects in chili plants is indeed low, namely that only a few species are found consisting of one family.

In addition, it can be seen from the research results that the level of natural enemy insect diversity, which is classified as moderate, is also followed by evenness data, which is not classified as high either. It can occur because several species of natural enemy insects dominate the research area, for example, Paratrechina longicornis, Anoplolepis gracilipes, and Exorista sp. The results obtained are different from those reported by Putra \& Utami (2020) that the evenness of the species of natural enemies they get is high. The difference in yields obtained can occur because other plants influence them near the chili plantations (Bernstein et al., 1991).

\section{The abundance of Natural Enemy Insects}

In this study, seven insect orders (1,196 individuals and 17 species) act as predators and three insect orders (236 individuals and 13 species) as parasitoids in chili plantations at the research location. The order with the highest abundance of individuals and species was Hymenoptera (Table 2). The Hymenoptera order is an order that has a large number of families in nature when compared to other orders. The Hymenoptera order is divided into two suborders, namely the Symphyta and Apocrita suborders (Trianto \& Marisa, 2020). These two suborders are mostly recognized as natural enemies and are key species in an area (Forbes et al., 2018). It is also supported by Stahlhut et al. (2013) stated that most insect species belonging to the order Hymenoptera act as natural enemies. It was further explained that more than 250 species of the order Hymenoptera are parasitoid insects. In nature, Hymenoptera is known as an insect that lives side by side with the agricultural world, both as a (Bischoff et al., 2013; Miall et al., 2020) parasitoid, predators, and only a few play a role as insect pests (Miall et al., 2020; Stahlhut et al., 2013).

Furthermore, the results obtained in this study are also following those reported by Kurniawati (2015) that the order with the most incredible abundance of individuals and families found and acting as natural enemy insects is Hymenoptera. Meanwhile, the 
least abundant orders of individuals and families are Dermaptera and Strepsiptera (Table $3)$. Both orders are members of insects with a low abundance compared to other orders (Pohl \& Beutel, 2013). According to Kurniawati (2015), the order Dermaptera is an insect with the characteristics of living in hiding, so the possibility of being found is very low. Meanwhile, the Strepsiptera order itself is a type of endoparasite for several kinds of insects, either acting as pests or pollinators. The low abundance of the Strepsiptera order is because this type lives attached to the host's body, making it difficult to find.

It can be seen from the abundance of natural enemy insect species obtained, the species with the highest number of individuals were Paratrechina longicornis (584 individuals) as predatory insects and Exorista sp. (105 individuals) as parasitoid insects (Table 2). P. longicornis is one of the insect species from the order Hymenoptera, and the family Formicidae obtained in this study. This species has the highest abundance compared to other predatory insect species because this is species has a way of living in colonies so that many individuals who fall into the traps. In addition, this can also occur because this species is known as "black crazy ant," which has an extensive range of ranges and very diverse types of feed, so it is possible to survive better than other species (Qodir et al., 2017). According to Vanderhaegen et al. (2019), P. longicornis is an insect species that is found in many residential areas. It is also one factor that causes this species to have a high abundance in the study area, considering that the research location is close to residential areas. Furthermore, Exorista sp. is one of the insect species from the order Diptera and the Tachinidae family found in the study. This species is a parasitoid that usually parasites the eggs of other insect species (Qodir et al., 2017).

\section{Distribution Pattern of Natural Enemy Insect}

In an ecosystem, there are three basic patterns of distribution of a species that has been recognized, namely random, clustered, and uniform (Ludwig \& John, 1989). To identify the distribution pattern of a species, various distribution indices can be used, for example, the Morisita index, which has been standardized. Based on the distribution pattern analysis results in Table 3, the distribution pattern of natural enemy insects on chili plants in Bincau Village is grouped. This can be seen from the Morisita index value (Id) $>1$ at all sampling times.

The distribution pattern of natural enemy insect groups in this study can occur because it is influenced by several factors, such as those caused by a combination of several factors in the environment, the social behavior of natural enemy insects, the ability to reproduce, the interaction of natural enemy insects, and a combination of the four these factors (McCoshum et al., 2016; Omkar \& Pervez, 2016). Furthermore, the distribution pattern of natural enemy insects in this study is also influenced by the presence or absence of prey or hosts. It is consistent with the statement of Omkar \& Pervez (2016) stated that the distribution of natural enemy insects in nature is influenced by the presence or absence of prey or hosts of these natural enemies in an ecosystem. Saeed et al. (2015) added that the presence or absence of other plants besides chilies in 
an area would undoubtedly affect the distribution of herbivorous insects, which are prey organisms or hosts of insect pests in an ecosystem. Hence, herbivorous insects in chili plants are also factors that can influence the formation of distribution patterns of natural enemy insects. It is also supported by the research results of and Staab \& Schuldt (2020), which stated that the existence of natural enemies in nature would be influenced by the presence of an abundance of herbivorous insects. As additional information, Kurniawati (2015) explains that the presence of herbivorous insects is influenced by the presence or absence of host plants in an ecosystem.

\section{Environmental Parameters}

Based on the results of the calculation of environmental parameters on chili plantations in Bincau Village, the average temperature obtained was $27.72^{\circ} \mathrm{C}$, humidity 74.9\%, and light intensity 1117.8 (Table 4). Furthermore, the environmental parameter data obtained were analyzed using the PCA method with PAST3 software. The purpose of this analysis is to see the dominant characters that affect the diversity, abundance, and distribution patterns of natural enemy insects (Trianto \& Purwanto, 2020).

Correlation analysis between groups produces Eigenvalue and\% Variance, as shown in Table 5. While the Scatter plot is shown in Figure 2, and the loading plot of the component is shown in Figure 3. Based on the analysis results above, it is known that temperature is the environmental parameter that has the most influence on diversity. , abundance, and distribution patterns of natural enemy insects in chili plantations in Bincau Village. It can be seen from the line's length formed in Figure 2 and the height of the graph in Figure 3 (Trianto \& Purwanto, 2020; Yudha et al., 2019). That is also following the statement by Medeiros et al. (2019) that temperature is one of the environmental parameters that affect the presence of natural enemy insects in an ecosystem. The temperature obtained in this study is the optimum temperature required by natural enemy insects to reproduce. According to Trianto et al. (2020), the optimum temperature required by natural enemy insects to support survival is in the range of $26-31^{\circ} \mathrm{C}$.

\section{Conclusion}

This study concludes that the diversity of natural enemy insects in chili (Capsicum annum L.) in Bincau Village, Martapura District, Banjar Regency is moderate ( $\left.\mathrm{H}^{\prime}=2.396\right)$. Furthermore, the highest abundance in this study was Hymenoptera, which consisted of 9 families, 16 species, and 1,009 individuals. The distribution pattern of natural enemy insects in chili plantations is clustered ( $\mathrm{Id}>1)$. 


\section{References}

Adnyana, I. N. S., Darmawan, D. P., Windia, I. W., \& Suamba, I. K. (2020). Agribusiness development model for strengthening the chili-tobacco intercropping farmer group. International Journal of Life Sciences, 4(1), 26-36. https://doi.org/10.29332/ijls.v4n1.387

Bernstein, C., Kacelnik, A., \& Krebs, J. R. (1991). Individual Decisions and the Distribution of Predators in a Patchy Environment. II. The Influence of Travel Costs and Structure of the Environment. The Journal of Animal Ecology, 60(1), 205. https://doi.org/10.2307/5455

Bischoff, M., Lord, J. M., Robertson, A. W., \& Dyer, A. G. (2013). Hymenopteran pollinators as agents of selection on flower colour in the New Zealand mountains: Salient chromatic signals enhance flower discrimination. New Zealand Journal of Botany, 51(3), 181-193. https://doi.org/10.1080/0028825X.2013.806933

Forbes, A. A., Bagley, R. K., Beer, M. A., Hippee, A. C., \& Widmayer, H. A. (2018). Quantifying the unquantifiable: Why Hymenoptera, not Coleoptera, is the most speciose animal order. BMC Ecology, 18(1), 1-11. https://doi.org/10.1186/s12898-018-0176-x

Ghazali, A., Asmah, S., Syafiq, M., Yahya, M. S., Aziz, N., Tan, L. P., ... Azhar, B. (2016). Effects of monoculture and polyculture farming in oil palm smallholdings on terrestrial arthropod diversity. Journal of Asia-Pacific Entomology, 19(2), 415-421. https://doi.org/10.1016/j.aspen.2016.04.016

Gunawardene, N. R., \& Taylor, C. K. (2012). New records of Elasmus (Hymenoptera, Eulophidae) species from barrow island, Western Australia. Journal of Hymenoptera Research, 29(15 october 2012), 21-35. https://doi.org/10.3897/JHR.29.3605

$\mathrm{Hu}, \mathrm{Z}$. (2020). What socio-economic and political factors lead to global pesticide dependence? A critical review from a social science perspective. International Journal of Environmental Research and Public Health, 17(21), 1-22. https://doi.org/10.3390/ijerph17218119

Kurniawati, N. (2015). Keragaman dan Kelimpahan Musuh Alami Hama pada Habitat Padi yang Dimanipulasi dengan Tumbuhan Berbunga. Ilmu Pertanian (Agricultural Science), 18(1), 31. https://doi.org/10.22146/ipas.6175

Ludwig, J., \& John, R. (1989). Statistical Ecology A Primer On Metods and Compling. New York: John Wiley dan Sons.

Magurran, A. E. (2004). Measuring biological diversity. Choice Reviews Online (Vol. 42). USA: Blackwell Publishing Ltd. https://doi.org/10.5860/choice.42-1547

Mariyono, J., \& Bhattarai, M. (2009). Chili production practices in Central Java, Indonesia: a baseline report (Issue September). 
McCoshum, S. M., Andreoli, S. L., Stenoien, C. M., Oberhauser, K. S., \& Baum, K. A. (2016). Species distribution models for natural enemies of monarch butterfly (Danaus plexippus) larvae and pupae: distribution patterns and implications for conservation. Journal of Insect Conservation, 20(2), 223-237. https://doi.org/10.1007/s10841016-9856-z

Medeiros, H. R., Grandinete, Y. C., Manning, P., Harper, K. A., Cutler, G. C., Tyedmers, P., ... Ribeiro, M. C. (2019). Forest cover enhances natural enemy diversity and biological control services in Brazilian sun coffee plantations. Agronomy for Sustainable Development, 39(6), 50. https://doi.org/10.1007/s13593-019-0600-4

Morgan, W., \& Shearer, D. (2007). Vegetable value chains in Eastern Indonesia - a focus on chilli (Issue May). ACIAR GPO Box 1571 Canberra ACT 2601 Australia.

Miall, J. H., Abram, P. K., Cappuccino, N., Bennett, A. M. R., Fernández-Triana, J. L., Gibson, G. A. P., \& Mason, P. G. (2020). Addition of nectar sources affects a parasitoid community without improving pest suppression. Journal of Pest Science, 93(4), 1-12. https://doi.org/10.1007/s10340-020-01274-y

Omkar, \& Pervez, A. (2016). Ladybird Beetles. In F. E. Vega \& R. W. Hofstetter (Eds.), Ecofriendly Pest Management for Food Security (pp. 281-310). Elsevier Inc. https://doi.org/10.1016/B978-0-12-803265-7.00009-9

Pazikowska-Sapota, G., Galer-Tatarowicz, K., Dembska, G., Wojtkiewicz, M., Duljas, E., Pietrzak, S., \& Dzierzbicka-Glowacka, L. A. (2020). The impact of pesticides used at the agricultural land of the Puck commune on the environment of the Puck Bay. PeerJ, 2020(3), 1-21. https://doi.org/10.7717/peerj.8789

Pohl, H., \& Beutel, R. G. (2013). The Strepsiptera-Odyssey: the history of the systematic placement of an enigmatic parasitic insect order. Entomologia, 1(e4), 17-26. https://doi.org/10.4081/entomologia.2013.e4

Putra, I. L. I., \& Utami, L. B. (2020). Keanekaragaman Serangga Musuh Alami Pada Tanaman Cabai Di Desa Wiyoro, Kecamatan Banguntapan, Kabupaten Bantul, Yogyakarta. Al-Kauniyah: Jurnal Biologi, 13(1), 51-62. https://doi.org/10.15408/kauniyah.v13i1.12253

Qodir, H. A., Maryana, N., \& Pudjianto, P. (2017). Biologi Scelio pembertoni Timberlake (Hymenoptera: Scelionidae) pada telur Oxya japonica (Thunberg) (Orthoptera: Acrididae). Jurnal Entomologi Indonesia, 14(2), 58-68. https://doi.org/10.5994/jei.14.2.58

Saeed, R., Razaq, M., \& Hardy, I. C. W. (2015). The importance of alternative host plants as reservoirs of the cotton leaf hopper, Amrasca devastans, and its natural enemies. Journal of Pest Science, 88(3), 517-531. https://doi.org/10.1007/s10340-014-06387 
Sativa, M., Harianto, H., \& Suryana, A. (2017). Impact of Red Chilli Reference Price Policy in Indonesia. International Journal of Agriculture System, 5(2), 120. https://doi.org/10.20956/ijas.v5i2.1201

Schinner, F., Kandeler, E., Ohlinger, R., \& Margesin, R. (2014). Methods in Soil Biology (1st ed.). German: Springer Berlin Heidelberg. https://doi.org/10.1 0071978-3-64260966-4

Souza, I. L., Tomazella, V. B., Santos, A. J. N., Moraes, T., \& Silveira, L. C. P. (2019). Parasitoids diversity in organic sweet pepper (capsicum annuum) associated with basil (ocimum basilicum) and marigold (tagetes erecta). Brazilian Journal of Biology, 79(4), 603-611. https://doi.org/10.1590/1519-6984.185417

Staab, M., \& Schuldt, A. (2020). The Influence of Tree Diversity on Natural Enemies-a Review of the "Enemies" Hypothesis in Forests. Current Forestry Reports, 6(4), 243259. https://doi.org/10.1007/s40725-020-00123-6

Stahlhut, J. K., Fernández-Triana, J., Adamowicz, S. J., Buck, M., Goulet, H., Hebert, P. D. N., ... Smith, M. A. (2013). DNA barcoding reveals diversity of Hymenoptera and the dominance of parasitoids in a sub-arctic environment. BMC Ecology, 13 (26 January), 2-13. https://doi.org/10.1186/1472-6785-13-2

Trianto, M., \& Marisa, F. (2020). Diversity of Hymenoptera Insect in Cowpea (Vigna sinensis L.) Agricultural Area at Martapura District, Banjar Regency, South Kalimantan. Natural Science: Journal of Science and Technology, 9(2), 29-33. https://doi.org/10.22487/25411969.2020.v9.i2.15174

Trianto, M., Marisa, F., Nuraini, \& Sukmawati. (2020). Keanekaragaman Jenis Rayap Pada Perkebunan Kelapa Sawit Dan Perkebunan Karet Di Kabupaten Banjar Kalimantan. Jurnal Biologi, 5(2), 199-209. https://doi.org/10.20956/bioma.v5i2.10716

Trianto, M., Marisa, F., Siswandari, N. P., Batuah, P., \& Sekumpul, P. (2020). Kelimpahan Nisbi, Frekuensi Dan Dominansi Jenis Lalat Di Beberapa Pasar Tradisional Di Kecamatan Martapura. Journal of Biological Sciences, 7(September), 21-29. https://doi.org/10.24843/metamorfosa.2020.v07.i02.p04

Trianto, M., \& Purwanto, H. (2020). Morphological characteristics and morphometrics of stingless bees (Hymenoptera: Meliponini) in Yogyakarta, Indonesia. Biodiversitas, 21(6), 2619-2628. https://doi.org/10.13057/biodiv/d210633

Tsurayya, S., \& Kartika, L. (2015). Kelembagaan dan Strategi Peningkatan Daya Saing Komoditas Daya Saing Komoditas Cabai Kabupaten Garut. Jurnal Manajemen Dan Agribisnis, 12(1), 1-12. https://doi.org/10.17358/jma.12.1.1 
Vanderhaegen, K., Naturinda, Z., Kouakou, L. M. M., Vanderheyden, A., \& Dekoninck, W. (2019). First record of the invasive longhorn crazy ant, Paratrechina longicornis (Latreille, 1802) (Hymenoptera: Formicidae) from Mt. Elgon, eastern Uganda. BioInvasions Records, 8(3), 505-514. https://doi.org/10.3391/bir.2019.8.3.05

Yudha, D. S., Pratama, M. Z. M., \& Eprilurahman, R. (2019). Antlers Characterization for Identification of Deer Species (Family Cervidae) in Indonesia. Journal of Tropical Biodiversity and Biotechnology, 4(3), 97. https://doi.org/10.22146/jtbb.45667 